NBER WORKING PAPER SERIES

\title{
ANTITRUST IN THE NOT-FOR-PROFIT SECTOR
}

\author{
Tomas J. Philipson \\ Richard A. Posner \\ Working Paper 12132 \\ http://www.nber.org/papers/w12132 \\ NATIONAL BUREAU OF ECONOMIC RESEARCH \\ 1050 Massachusetts Avenue \\ Cambridge, MA 02138 \\ March 2006
}

\begin{abstract}
Posner: The Law School, The University of Chicago, 1111 E. 60 Street, Chicago, IL 60637. We are grateful to seminar participants at Brigham Young University, Northwestern University, Northern Illinois University, RAND, Stanford, The University of Chicago, and The University of Montreal as well to Gary Becker, Dennis Carlton, and Casey Mulligan for their helpful comments. We are also grateful to Anup Malani and Meghan Maloney for their very helpful research assistance. The views expressed herein are those of the author(s) and do not necessarily reflect the views of the National Bureau of Economic Research.
\end{abstract}

(C)2006 by Tomas J. Philipson and Richard A. Posner. All rights reserved. Short sections of text, not to exceed two paragraphs, may be quoted without explicit permission provided that full credit, including () notice, is given to the source. 
Antitrust in the Not-For-Profit Sector

Tomas J. Philipson and Richard A. Posner

NBER Working Paper No. 12132

March 2006

JEL No. K2

\begin{abstract}
$\underline{\text { ABSTRACT }}$
Despite the conceptual differences between for-profit and non-profit firms stressed in conventional economic analyses of the non-profit sector, U.S. antitrust law generally does not distinguish between these two organizational forms. This paper argues that the same incentives to restrain trade exist in the non-profit sector as in the for-profit sector. Altruistic firms benefit from exploiting market power, just as non-altruistic ones do, even when they would price below cost without regard to competition. Therefore, promoting competition is socially valuable regardless of the particular objectives of producers, and the fact that antitrust law does not distinguish between the two sectors is efficient.
\end{abstract}

Tomas J. Philipson

Graduate School of Public Policy Studies

The University of Chicago

1155 E 60th Street

Chicago, IL 60637

and NBER

t-philipson@uchicago.edu

Richard A. Posner

The Law School

The University of Chicago

1111 E 60 ${ }^{\text {th }}$ Street

Chicago, IL 60637

richard posner@ca7.uscourts.gov 
The legal definition of a not-for-profit (NFP) enterprise is that it enjoys an exemption from taxation and at the same time operates under a nondistribution constraint - that is, any surplus of revenues over expenses cannot be distributed as profits to the firm's "owners." Much economic activity nowadays occurs in the NFP sector of the economy. Even when the sector is defined narrowly, as we shall do in this paper, as comprising only charitable nongovernmental enterprises (thus excluding government corporations such as Amtrak and the Postal Service, public universities and hospitals, and worker, business, and consumer cooperatives), it is estimated to produce one-fifth of all U.S. R\&D, much of the economy's human capital that is not produced by on-thejob training, many cultural products and services, and much of the nation's health care, which alone accounts for about one-sixth of all U.S. economic activity. About a fifth of all U.S. corporations are incorporated under NFP statutes.

A substantial amount of antitrust activity ${ }^{1}$ occurs in the NFP sector. Table 1 presents data on federal antitrust activity since 1980 in the health care industry, the largest industry in the sector ${ }^{2}$.

Table 1: Antitrust Cases Brought by the U.S. Department of Justice or Federal Trade Commission in the Health Care Sector since 1980

\begin{tabular}{|l|l|l|l|}
\hline Industry & FP & NFP & Total \\
\hline Hospitals & 20 & 17 & 37 \\
\hline Pharmaceuticals & 25 & 0 & 25 \\
\hline Health Insurers & 3 & 2 & 5 \\
\hline Physicians and physician groups & 58 & 9 & 67 \\
\hline HMO's & 2 & 0 & 2 \\
\hline
\end{tabular}


Antitrust in Nonprofit Sector

Total

\begin{tabular}{|l|l|l|}
\multicolumn{3}{|c}{3} \\
\hline 108 & 28 & 136 \\
\hline
\end{tabular}

If the pharmaceutical industry, which is entirely for-profit, is excluded, almost a third of the antitrust cases in the health-care industry involved NFPs. This is due in part to the fact that the community hospital industry, the most important industry in the NFP sector, recently experienced a merger wave. There were about a thousand mergers in the industry in the 1990s, an industry consisting of about five thousand hospitals of which about $60 \%$ are not-for profit. ${ }^{3}$

Conventional economic analysis of the NFP sector ${ }^{4}$ sharply distinguishes between the forprofit (FP) and NFP forms, which might seem to imply that the behavior of the two sectors is sufficiently different to warrant different antitrust treatment. It has been argued that non-profits solve an asymmetric information problem between donors (who cannot readily monitor the provision of the services that they wish to promote) and the providers of those services ${ }^{5}$ and have different, altruistic objectives from profit-maximizing firms. ${ }^{6}$ In either case, the fact that NFP firms do not distribute profits for private gain has persuaded some judges and scholars that nonprofit firms may not be as interested in exploiting market power as for-profit firms are assumed to be. ${ }^{7}$ Other judges and scholars have questioned that analysis and concluded that there are no significant differences in behavior of for-profit and not-for-profit firms that would justify a difference in antitrust treatment. ${ }^{8}$

Yet there is no general antitrust exemption for NFPs. ${ }^{9}$ There are three major categories of antitrust activity in the NFP sector. The first involves trade and professional associations and cooperatives. Although these entities are usually organized in the NFP form, they are agents of FP firms and individuals, and the courts sensibly pierce the NFP label and treat them as functionally 
Antitrust in Nonprofit Sector

FP entities. ${ }^{10}$ The second class of NFP antitrust cases involves educational institutions charged with collusion, for example collusion on financial aid to students or collusion on the grant of rights to broadcast intercollegiate sports events. ${ }^{11}$ The third major class of NFP antitrust cases involves challenges to mergers between NFP hospitals. ${ }^{12}$ In the second and third classes, defendants will often argue that their NFP status entitles them either to an outright exemption from antitrust scrutiny or to a different, more permissive standard of liability. These arguments fail. Should they? The main efficiency rationale for applying antitrust law to for-profit firms-that it reduces or eliminates the deadweight loss associated with market power- is equally applicable to non-profits. Even if producers care about consumers in addition to profits, with the result that the level of activity of the two types of firm differs-in particular, quantity and quality of output may be greater for an NFP firm than for an FP firm—-the incentive to change that behavior through collusion, and the adverse social consequences that result from that change, are similar. Altruism may lower prices but raise mark-ups relative to profit maximization because altruistic firms benefit from exploiting market power even when this would lead them to price below cost without regard to competition. For example, although many NFP universities in the US have tuition revenues below operating costs, thereby indicating below-average-cost pricing, some of these universities have been charged with collusive behavior that violates antitrust law. The important implication is that promoting competition is socially valuable regardless of the particular objectives of producers. The fact that antitrust law does not distinguish between the two sectors is thus consistent with our analysis. Indeed, we show that consumer-oriented antitrust policy may be more important for consumer-oriented than for conventional profit-maximizing firms in enhancing economic welfare. 
Antitrust in Nonprofit Sector

In addition to arguing that antitrust matters for the non-profit sector, we arrive at the counterintuitive implication that the effects of antitrust enforcement for this sector depend on the behavior of firms in the for-profit sector. Non-profit firms receive free capital in the form of donations, giving them a cost advantage that makes the marginal firms in their industry the for-profit firms, the firms that therefore drive the industry's response to policy measures, such as antitrust.

Our analysis relates to several strands of work on the NFP sector. Although there is a substantial economic literature on NFP firms, most of it is at the firm rather than the market level and so does not address issues of competition. ${ }^{13}$ There is also an empirical literature on the relative significance of concentration in raising price in the two sectors, particularly in the hospital industry, ${ }^{14}$ which to date has had mixed results.

\section{I: Restraint of Trade by Monopolies That Do Not Maximize Profits}

For a given level of output $y$, let $\pi(y) \equiv p(y) y-c(y)$ denote profits where $p(y)$ denotes the inverse demand function and $\mathrm{c}(\mathrm{y})$ the total cost of production. We assume that the firm is donoroperated in the sense of being operated by someone who has utility over his own consumption, $m$, and output $u(m, y) .{ }^{15}$ We call this "output preference." Output preference can arise from an altruistic concern with consumers, but need not. For example, professors who prefer research output to maximizing their pecuniary income may favor lower-than-maximum tuition in order to attract good students, teaching being a complement to research. Donors may give money to hospitals or universities to do research on diseases they have or fear without necessarily being altruistic. They seek an in-kind return on their investment, in terms of output, rather than a pecuniary return, as a for-profit investor would seek. Even donations that seem "purely" altruistic may be motivated also or instead by desire to signal wealth, culture, or generosity. Our analysis, how- 
Antitrust in Nonprofit Sector

ever, applies regardless of the precise motivation for participating in or contributing to not-forprofit activities.

The producer chooses output subject to the constraint that his consumption and costs cannot exceed unearned income, $m_{0}$, and revenues earned on productive output

$$
m+c(y)=m_{0}+p(y) y .
$$

The output choice thereby induces a utility function over output alone

$$
v(y)=\mathrm{u}\left(m_{\mathrm{o}}+\pi(y), y\right) .
$$

Donors forgo their own consumption to fund the activities of non-profit-firms; whatever costs are not picked up by sales are funded by donations. Donations are equivalent to negative profits. However, as donors do not give up all of their own consumption, there is always a tradeoff between profits and output.

The producer chooses the quantity to produce that will maximize his utility:

$$
d v / d y=u_{c} \pi_{y}+u_{y}=0 \Leftrightarrow-u_{y} / u_{c}=\pi_{y} .
$$

The feasible range for the consumption-output tradeoff is determined by the downwardsloping part of the profit-function. An output-preferring firm will always operate in that region and thus outproduce a profit-maximizing firm because if he did not, he would be better off expanding both consumption and output. Therefore, output is depicted only for levels, above the one that maximizes profits, $\pi_{*}=\pi\left(y_{*}\right)$, at which consumption is maximized. Unlike profit maximization, where only the budget set is affected by choice of output, the optimal choice for the NFP equates the marginal rate of substitution between consumption and output to the corresponding tradeoff in the market, as represented by the declining part of the profit-function. Donations, i.e., 
Antitrust in Nonprofit Sector

negative profits, are elicited if the output preference is strong enough to bring revenues below the cost of production. ${ }^{16}$

Rewriting the optimality condition, one obtains a generalized mark-up condition

$$
p(1-|\varepsilon|)=c_{y}-u_{y} / u_{c}
$$

where $\varepsilon \equiv p_{y} y / p$ is the elasticity of the inverse demand function. This is the standard mark-up condition adjusted by the marginal rate of substitution, $u_{y} / u_{\pi}$, between profits and output and may be reinterpreted as a reduction in the cost of production. The optimal price falls, and thus the optimal quantity rises, with the willingness of the monopolist to trade profits for output. However, although price will be lower, markups above competitive prices may be higher. ${ }^{17}$ Indeed, optimal price may involve a mark-down below, as opposed to a mark-up above, costs but at the same time be reduced by competition more than in the case of profit maximization. Mark-down below cost occurs when donations finance production to the extent that revenue through sales need not cover marginal or average costs.

An illustrative special case is where the producer's preferences are quasi-linear and the producer cares about consumers in terms of their surplus

$$
\begin{aligned}
& u(m, y)=m+z(s(y)) \\
& s(y) \equiv \int_{0 \leq q \leq y}[p(q)-p(y)] d q
\end{aligned}
$$

Substituting in $u_{y}=z_{s} p|\varepsilon|$, the mark-up condition has the compact form

$$
p\left[1-|\varepsilon|\left(1-z_{s}\right)\right]=c_{y}
$$

In this case, the marginal rate of substitution between consumer surplus and profits discounts the negative effect of the demand elasticity on price. This occurs because the gain in surplus from expanding output by reducing price to infra-marginal consumers, $s_{y}=-p_{y} y=p|\varepsilon|$, confers benefits 
Antitrust in Nonprofit Sector

on a producer who cares about consumers. When the producer does not care about consumers, i.e., when he maximizes profits as when $u_{y}=z_{s}=0$, the mark-up condition reduces to the conventional one.

\section{A. Socially Optimal Pricing}

The classic efficiency rationale for antitrust policy under profit maximization is that antitrust eliminates the deadweight loss associated with monopoly power. There are two components to this argument. The first is that socially optimal pricing differs from optimal monopoly pricing: marginal cost pricing is different from the optimal mark-up of price implied by monopoly power. Second, competition will lead to the socially optimal price: competition implies marginal cost pricing. This subsection establishes the first result for the case in which the firm does not maximize profits. The subsequent section establishes the second result for such a firm.

The output that maximizes social welfare $w(y)$ is comprised of the sum of producer and consumer welfare, $w(y) \equiv v(y)+s(y)$, satisfies the necessary first-order condition

$$
d w / d y=d v / d y+d s / d y=0
$$

This simple first-order condition illustrates the basic misalignment between producer-surplus and social-surplus maximization that exists even when firms do not maximize profits. Let $y_{v}$ and $y_{\mathrm{w}}$ denote the output levels that maximize firm utility $v$ and social welfare $w$ respectively. As the consumer surplus rises with output everywhere, $d s / d y>0$, the first-order condition for the socially optimal level of output implies that the producer must lose on the margin by expanding output farther; $d v / d y\left(y_{\mathrm{w}}\right)<0$, which is in conflict with the first-order condition defining the optimal output from the firm's own perspective; $d v / d y\left(y_{v}\right)=0$. Whether producers prefer output to 
Antitrust in Nonprofit Sector

profits or the reverse, the socially optimal level of output will be larger as the firm takes into account consumer surplus, which rises with output. ${ }^{18}$

This general misalignment between producer welfare and social welfare implies that marginal cost pricing is not the norm by which social efficiency should be evaluated, as it is in the case of profit maximization. We derive the socially optimal price by noting that the social welfare function $w$ for a monopolist with preferences $u$ can be reinterpreted as the objective function of a monopolist with preferences $w=u+s$. The socially optimal price that satisfies the reinterpreted monopoly condition is

$$
p[1-|\varepsilon|]=c_{y}-w_{y} / w_{c}=c_{y}-\left[u_{y}+s_{y}\right] / u_{c} .
$$

Since $s_{y}=p|\varepsilon|$, we can rewrite this condition as

$$
p\left[1-|\varepsilon|\left(1-1 / u_{c}\right)\right]=c_{y}-u_{y} / u_{c} .
$$

The socially optimal price discounts the optimal price for the monopolist even though the monopolist may well care about consumers. This means that the socially optimal price will often be below cost.

Consider by way of illustration the case in which the monopolist cares about consumer surplus as much as does about profits:

$$
u=\pi+s
$$

In that case the monopoly price will equal marginal cost, the benchmark competitive price for efficient for-profit production. But the socially optimal price will involve a discount below cost

$$
\begin{aligned}
& p\left(y_{v}\right)=c_{y} \\
& p\left(y_{\mathrm{w}}\right)=c_{y} /(1+|\varepsilon|)
\end{aligned}
$$


Thus, even though a supplier may be altruistic, he may not be altruistic enough, when acting only to satisfy his own desires, to set the socially optimal price. The efficient output requires that price be set below marginal cost because the producer desires to reduce his own consumption in order to finance additional output. This implies the counterintuitive but fundamental proposition that an efficient antitrust policy in the NFP sector should not seek merely to equate price to marginal cost, because output may be restricted (from a social standpoint) even at that level; the goal of antitrust in such a case is to force price below marginal cost. ${ }^{19}$

\section{B. Competition and Socially Optimal Pricing}

To study the impact of competition on socially optimal pricing, we consider a homogeneous model of Cournot competition with an inverse demand curve $p(Y)$ for the total quantity of $i=1,2, . . n$ firms; $Y=\Sigma y_{i}$. Under the output levels represented by the vector $\mathbf{y} \equiv\left(y_{1}, . ., y_{\mathrm{n}}\right)$ the $n$ producers are assumed to have utility functions $\left(v_{1}(\mathbf{y}), \ldots, v_{\mathrm{n}}(\mathbf{y})\right)$ over profits and output, as in

$$
v_{i}(\mathbf{y})=u\left(\pi_{i}(\mathbf{y}), y_{i}\right)
$$

where $\pi_{i}(\mathbf{y}) \equiv p(Y) y_{i}-c\left(y_{i}\right)$ are the profits of the $i^{\text {th }}$ firm under a given vector of output. It is straightforward to show that the necessary first-order condition is

$$
p\left(1-m_{i}|\varepsilon|\right)=c_{\mathbf{y}}-u_{\mathbf{y}} / u_{\pi}, \quad i=1,2, . ., n
$$

where $m_{i}=y_{i} / Y$ is the market share of the $i^{\text {th }}$ firm. As was true for the monopoly case, the firstorder condition is simply a reinterpretation of the condition under profit maximization, with the costs of production lowered because of output preference.

If increased competition is defined as an increase in the number of producers, $n$, the socially optimal price converges to the efficient price as $n$ goes to infinity by making the market share, $m$, of each firm go to zero. This is the generalized result of the case of profit maximization, where 
Antitrust in Nonprofit Sector

perfect competition leads to socially optimal marginal-cost pricing. The key point is that although the levels of output may be more desirable from a consumer perspective under altruism, induced by the effect of $u_{y} / u_{\pi}$, the change in the behavior induced by market power, caused by the effect of $m$, is similar across producer objectives. Competition, the subject of antitrust policy, is valuable to consumers in both cases even though they may prefer an altruistic producer to a selfish one.

This analysis implies a general efficiency rationale for promoting competition regardless of producer preferences. Competition, whether with profit maximizers or just with other NFP firms, might drive the price of the altruistic firm's output to a level so far below cost that the personal utility loss of the donors exceeded their utility gain from the benefit of the low price to the firm's customers. If that were the case, the firm would have an incentive to collude with its competitors to raise price, albeit not all the way to its costs.

\section{The Value of Collusion by Altruistic Producers}

When we consider an oligopoly industry, we discover some important differences from the monopoly case. Generally, altruistic producers will gain from coordinating their activities because the behavior of each firm affects the overall utility, as opposed to simply profits, of other firms. It may be that collusion expands output and raises welfare, rather than restricts output and lowers welfare, among altruistic producers.

Under the output levels $\mathbf{y} \equiv\left(y_{1}, . ., y_{\mathrm{n}}\right)$ among $n$ producers with utility functions $\left(v_{1}(\mathbf{y}), \ldots, v_{n}(\mathbf{y})\right)$, their joint utility is

$$
\mathrm{V}(\mathbf{y}) \equiv \Sigma v_{i}(\mathbf{y})=\Sigma u_{i}\left(\pi_{i}(\mathbf{y}), \mathbf{y}\right)
$$


Antitrust in Nonprofit Sector

Note that the utility of each firm is assumed to depend on the entire output vector, including the outputs of other firms, as would be the case, for example, if some producers cared about aggregate output or consumer surplus. The output levels that are optimal with respect to the industry satisfy the necessary first-order conditions

$$
\begin{aligned}
d \mathrm{~V} / d y_{j}=\sum d v_{i}(\mathbf{y}) / d y_{j}=[ & \left.\left(d u_{j} / d \pi\right)\left(d \pi_{j} / d y_{j}\right)+d u_{j} / d y_{j}\right]+ \\
& \sum_{i \neq j}\left[\left(d u_{i} / d \pi\right)\left(d \pi_{i} / d y_{j}\right)+d u_{i} / d y_{j}\right]=0
\end{aligned}
$$

The first bracketed term is the marginal conditions for the $j^{\text {th }}$ firm when expanding its output. The second term consists of the external effects on other firms from that output expansion. This second external effect has two offsetting parts: the negative impact on profits induced by a lower price and the positive impact that extra output has on other firms that value output. Whether the net externality is negative or positive determines whether collusion produces less or more output than the private equilibrium. The more altruistic firms are, as measured by the marginal rate of substitution between output and profits, the more likely it is that the positive external effect will dominate.

To illustrate, consider a homogeneous constant-returns industry with a constant elasticity of demand in which aggregate output is valued according to

$$
u_{i}=\pi_{i}+\alpha Y .
$$

In this case the relative size of the socially optimal output from the industry's perspective, $Y_{s}$, differs from the output of a private (Nash) equilibrium, $Y_{\mathrm{p}}$, satisfies

$$
\ln Y_{s} / Y_{\mathrm{p}}=-(1 /|\varepsilon|)[(c-\alpha)(1-|\varepsilon| / n) /(c-n \alpha)(1-|\varepsilon|)]
$$


Antitrust in Nonprofit Sector

It follows that the ratio rises in altruism $\alpha$. In particular, the social optimum goes from being below the private optimum at low levels of altruism, $Y_{s} / Y_{p}<1$ for low $\alpha$, to being above it for high levels of altruism.

So in industries in which it is clear that the value of output expansion is more important than the cost of price reductions, such as industries in which output is sold at zero price, there is social value in collusion to reduce free-riding. For example, welfare organizations should be allowed to divide markets geographically in order to serve the largest possible poor population. But when the NFP firm cares only about firm-level, rather than industry-level, output, collusion will restrict output and should be forbidden. This situation is evidenced by firm-specific, as distinct from industry-wide, donations, such as alumni donations to universities or patient donations to hospitals. In contrast, when donations are industry-wide, as in donations to organizations like United Way or the Red Cross, collusion may expand output.

Regardless of whether a firm has an incentive to collude with its competitors in restricting or expanding output, it will often have an incentive to collude with its competitors to lower the price of its inputs through the exercise of monopsony power. Utility-maximizing firms always prefer lower costs. Indeed, the most common type of collusion in the NFP sector, is probably monopsonistic, as in avoiding competition to "buy" minority students or student athletes. Until challenged by an antitrust suit, the Ivy League colleges colluded to deny scholarships based on merit rather than need in order to increase scholarships for minority students without a net increase in scholarship expense. ${ }^{20}$ The National Collegiate Athletic Association (NCAA), a consortium of nonprofit colleges and universities, appears to operate much like a conventional cartel 
Antitrust in Nonprofit Sector

designed in this case to reduce the cost of student athletes. ${ }^{21}$ The welfare effects are presumably the same as with other monopsonies.

\section{The Welfare Loss of Altruistic Restraint of Trade}

Although we have argued that the standard rationale for antitrust—-the avoidance of deadweight loss-generalizes to NFPs, one may suspect that the deadweight loss created by them would be small compared to that created by firms interested only in higher profits. After all, if a producer cares about consumers, the loss he imposes on them should be smaller than if he does not care. However, our analysis produces the counterintuitive result that often monopolization is more harmful when done by altruistic producers than when done by profit-maximizing firms.

Consider an altruistic producer with preferences $u\left(m_{0}+\pi(y), y ; \alpha\right)$ parameterized by the degree of output-preference $\alpha$. If we denote the monopolistic and competitive outputs by $y_{M}(\alpha)$ and $y_{C}(\alpha)$ respectively, then the welfare loss, $L(\alpha)$, is

$$
L(\alpha) \equiv \int y_{M}(\alpha)_{\leq q \leq} y_{C}(\alpha)\left[p(q)-p\left(y_{C}(\alpha)\right)\right] d q .
$$

Altruism has two effects on the welfare loss brought about by monopolization. The first is through the reduction in output brought about by monopolization, the second through its effect on the average surplus lost as a result of that reduction. Altruism will often entail larger losses of output, and these losses will occur further down the inverse demand curve, because the altruist's output is often larger than a profit-maximizing firm's output. Therefore, unless the inverse demand curve is highly convex, so that the average surplus lost is larger when lost at low levels of output, altruism will increase the welfare loss from monopolization. Even though the effects of altruism on output are positive, market power may be more damaging under altruism. 
To illustrate, consider the case in which demand curves are linear, $p(y)=a-b y$, and the altruist has the quasi-linear preferences $u(\pi, y ; \alpha)=\pi+\alpha y$. In this case, the monopoly output will be half the competitive output and the monopoly price halfway up the demand curve from the competitive price:

$$
\begin{aligned}
& y_{C}-y_{M}=y_{M}=[a-(c-\alpha)] / 2 b \\
& p_{M}-p_{C}=[a-(c-\alpha)] / 2 .
\end{aligned}
$$

These price and quantity effects imply that the deadweight loss is

$$
L(\alpha)=\left[y_{C}-y_{M}\right]\left[p_{M}-p_{C}\right] / 2=(1 / 4 b)[a-(c-\alpha)]^{2}
$$

In this case, both the output lost and the average surplus lost by excluded consumers increase with altruism, so that altruism has a positive effect on deadweight loss, $d L / d \alpha>0 .{ }^{22}$

More generally, the positive impact of altruism on the efficiency loss from market power comes from the fact that altruistic firms act as if they have lower costs, and the efficiency loss caused by market power tends to decrease with costs.

\section{E. Multiple-Product Monopoly}

Altruistic firms may use their market power to discriminate in favor of some consumers at the expense of others. ${ }^{23}$ For example, hospitals or universities may charge poor consumers less at the expense of rich ones if expanding the output for poor is part of their mission. With altruistic preferences, discrimination may involve using market power in one market to subsidize belowcost selling in the other. ${ }^{24}$ Several aspects of such cross-subsidization are worth noting. First, it may be consistent with perfect competition. Second, it should not be confused with predatory pricing. And third, as is true for the case of profit-maximizing firms, the feasibility of price discrimination depends on the cost of preventing arbitrage. 
Antitrust in Nonprofit Sector

Consider a monopoly producer that has two output levels, $y_{P}$ and $y_{R}$, but for which the monopolist only has output preference for the first group (the poor) but not for the second (the rich). The monopolist's preferences are then

$$
v\left(y_{R}, y_{P}\right)=u\left(m_{0}+\pi\left(y_{R}, y_{P}\right), y_{P}\right)
$$

where profits are

$$
\pi\left(y_{R}, y_{P}\right)=p_{R}\left(y_{R}\right) y_{R}+p_{P}\left(y_{P}\right) y_{P}-c\left(y_{R}, y_{P}\right)
$$

If costs are separable, so that serving the poor does not affect the cost of serving the rich, profits will be maximized in the rich market at a level denoted $\pi^{*}$. The market simply acts to expand the consumption-output choice on its income-expansion path from $\left[c\left(m_{0}\right), y_{\mathrm{P}}\left(m_{0}\right)\right]$ to $\left[c\left(m_{0}+\pi^{*}\right)\right.$, $\left.y_{P}\left(m_{0}+\pi^{*}\right)\right]$. Part of the extra income $\pi^{*}$ gained from the market power in the rich market will be spent on extra consumption and part of it on extra output for the poor. Whether in funding the consumption of the donor or the output of the poor, this use of market power entails an inefficient use of resources. If competing NFPs got together and agreed to charge rich patients uniformly high prices for medical care in order to subsidize the provision of medical care to poor patients, the NFPs would be taxing the rich—forcing them to finance a portion of the NFPs' charitable activities for the poor. In particular, the amount of donations would be determined by the total profits in the rich and poor market. Donations would fall if the profit on the sales to the rich rose more than the profit on sales to the poor declined:

$$
d\left[\pi^{*}+\pi_{P}\left(y_{P}\left(m_{0}+\pi^{*}\right)\right)\right] / d \pi^{*}=1+\left(d \pi_{P} / d y_{P}\right)\left(d y_{P} / d \pi^{*}\right)
$$

Thus market power in the rich market could lead the donor to donate less, shifting the burden of subsidizing the poor to the rich consumers, even though they may not care about the poor as much as the donor does, in which event there could be a decline in total utility. A further 
Antitrust in Nonprofit Sector

complication, however, concerns competition between such a firm and profit maximizers serving both markets. The latter would operate at levels of output that satisfied the standard marginal conditions. A firm with output preference for the poor would operate at a higher output level, but if its two outputs are complements - that is, if serving the poor lowers the cost of serving the rich on a per-person basis (and vice versa) — then the altruistic firm has a competitive advantage over a for-profit firm that serves the same two markets. This occurs because its larger output in its main activity (for example, serving the poor) lowers its costs in the complementary activity. ${ }^{25}$

Price discrimination as such does not violate antitrust law. In the case just given, where the nondistribution constraint prevents the firm from obtaining monopoly profits overall, discrimination produces a net gain in efficiency. If, however, a firm that has a monopoly in one market uses the profits that it obtains there to sell below cost in another market with the aim and probable effect of driving an equally or more efficient competitor out of that market (or preventing a competitor from entering), it will violate section 2 of the Sherman Act regardless of the monopolist's NFP status. If an NFP sells below cost merely because it derives utility from the additional output that such pricing enables, it is not really selling below cost and there is no antitrust violation. If however it sells below cost with the additional objective of driving out an equally or more efficient competitor (or competitors) so that it can charge a higher price, albeit still a price below cost, then it would be in antitrust jeopardy.

\section{II: Competition and Antitrust in Mixed Industries}

In this section, continuing the discussion begun at the end of the preceding section, we consider "mixed" industries, that is, industries that consist of both NFP and FP firms, as in the hospital industry and to a lesser extent the education industry. The previous analysis showed that the 
Antitrust in Nonprofit Sector

standard rationale for antitrust was as applicable to altruistic firms as it was to profit-maximizing firms. In this section we arrive at the surprising implication that the effects of enforcing anti-trust in the non-profit sector often depend on the supply behavior of the for-profit sector.

If NFP firms have lower costs because of their free capital (and perhaps free labor) and this leads them to price their output below marginal cost, then the only reason for the existence of FP firms in the same industry would be a scarcity of altruists—-that is, insufficient labor or capital contributed by charitable donors to provide productive capacity sufficient to supply the entire market at a price equal to marginal cost. On this view, the FP firms in a mixed industry correspond to the fringe firms in a dominant-firm industry (George J. Stigler 1968), that is, an industry in which one firm has a stable dominant market share because its average cost curve is below that of the other firms throughout most but not all of the range of feasible output. The market price will be equal to the marginal cost of the fringe firms, which here would correspond to firms in the for-profit sector.

It might seem to follow that, provided the antitrust laws are enforced against FP firms, compressing their price to marginal cost, there is no need to enforce the antitrust laws against NFP firms in mixed industries. But this is incorrect. The NFP firms may collude to reduce their output. The resulting increase in price will induce an expansion of output by the fringe of FP firms. Assuming that firms in the fringe have rising average costs and that the expansion of the fringe's output takes the form of the existing firms' increasing their output rather than new firms' entering whose average costs are identical to the average costs of the existing firms, the result will be an increase in the industry's marginal cost, and so the output of the industry will be lower than before. (This is just an application of Stigler's theory of how a dominant firm, provided it has a 
Antitrust in Nonprofit Sector

cost advantage, can obtain monopoly profits notwithstanding the existence of a competitive fringe in its market.)

This analysis is similar to the issues addressed by the Landes-Posner market-power model. ${ }^{26}$ The higher the elasticity of supply of the fringe firms, the higher the elasticity of demand of the firm whose market power we're interested in measuring. And likewise the lower the market share of that firm, the higher the elasticity of demand facing it. Of course, if the elasticity of supply of the fringe firms is infinite, the nonfringe firms have no market power regardless of their market share, provided the market share of the nonfringe firms exceeds zero percent, however slightly. And if the elasticity of supply of the fringe firms is zero because the optimal price charged by the nonfringe firms is below the cost of the fringe firms throughout the entire feasible range of output, then the fringe firms have no effect on the elasticity of demand of nonfringe firms. The realistic case, however, has fringe firms with nonzero elasticity of supply and an aggregate market share significantly greater than zero.

Consider now a market in which the nonfringe firms are two NFPs each with 40 percent of the market, and there is a fringe of FPs that supply the other 20 percent of the market demand. Even though there is a competitive fringe that can expand its output if the nonfringe firms raise their price (for we're assuming a positive elasticity of supply), a merger of or collusion between the two NFPs would result in a higher price (assuming that costs remain unchanged) because their joint market share would now be greater than it was before the merger of collusion. For example, suppose the market elasticity of demand and the elasticity of supply of the fringe firms are both 1; then before the merger or collusion the elasticity of demand facing each of the NFP 
Antitrust in Nonprofit Sector

firms would have been 4; afterwards it is only 1.5, implying a substantial increase in market power.

This analysis shows that antitrust cannot ignore NFP firms in mixed markets merely because they have lower costs than FP firms so that the market price is determined by the costs of the FP firms. But in addition it is not certain that NFP firms will, merely because of their output preference, be the low-cost producers. The nondistribution constraint may limit NFPs' access to capital and ability to incentivize their employees, and these disadvantages may outweigh the lower costs that are due to altruism (and resulting output preference) and to tax-exempt status.

\section{A. The Competitive Disadvantage of Profit-Maximizing Firms}

Consider to begin with competition between altruists and profit maximizers without worrying about the legal regulations that by defining constrain the nonprofit sector. In the long run, given free entry and exit in a competitive market, the breakeven combinations of output and price $(y, p)$ at which a producer is indifferent between entry and exit are defined by

$$
v(y, p y-c(y))=v(0,0) .
$$

Under profit maximization, these combinations reduce to the familiar average cost curve $p=c(y) / y$, which is assumed to have the standard U-shape. If a firm values output in itself, profits along the breakeven curve are always negative, implying that donations are made. Specifically, $v_{y}>0$ and $v(y, \pi)=v(0,0)$ implies $\pi<0$. Such a firm has average monetary costs above price. As a result, the firm's sales do not cover costs, and donations make up the shortfall. If there were an infinite number of potential suppliers of each type $v$, then in the long run, price would move to its lowest point along the breakeven curve of all types. This simply corresponds to the lowest-cost 
Antitrust in Nonprofit Sector

suppliers surviving in the for profit case. In the case of two firm types, the lowest sustainable price is $p_{l}$ for the profit-maximizing firms and $p_{0}<p_{1}$ for the profit-deviating firms.

The above analysis implies the surprising result that profit maximizers can never survive against competition from an infinite supply of profit-deviating firms. This competitive advantage of profit deviators is most easily understood by realizing that the cost of capital is lower for profit-deviating firms; donations represent capital obtained at zero cost, because they require no interest payments and the firm may simply keep the principal. The fact that nonprofit firms spend money soliciting and competing for the capital of donors provides evidence that donors, and thus profit-deviating firms, must be in finite supply. We will assume this form of scarce altruism by taking as given that there are $A$ potential profit-deviating firms. Because we do not take a stand on what determines the number or market share of the $A$ firms, we will provide predictions based not on the level of nonprofit activity but instead on the changes in nonprofit activity induced by variations in market incentives. This resembles the approach of neoclassical theory, which avoids explaining the level of production and focuses on the changes in production induced by varying market conditions.

If profit maximizers coexist with $A$ profit-deviating firms, profit-maximizers will be the marginal firms, whose behavior governs marginal changes in industry price and quantity. This implies that in a mixed industry with competition, the long-run behavior of industry output and price when the for-profit sector is perfectly elastic are unaffected by the presence of profitdeviators. To see this more precisely, consider a case in which preferences are indexed by a parameter $\alpha$ in [0,1]. A firm $\alpha$ has the utility function $v(y, \pi \mid \alpha)$, with $\alpha=0$ for profit-maximizers, and $v_{y}(y, \pi \mid \alpha \$)$ increasing in $\alpha .{ }^{27}$ Suppose the $A$ profit-deviators are distributed according to 
Antitrust in Nonprofit Sector

$G(\alpha)$, where $\mathrm{G}$ has support $\alpha$ in $\$(0,1]$. These firms act as if they were profit-maximizers with the cost functions $C(y \mid \alpha)^{28}$, where marginal and average cost fall in $\alpha$. Intuitively, since such firms value output intrinsically, their overall (pecuniary plus non-pecuniary) costs are lower. Profit-maximizing firms, those with the highest average and marginal cost, can survive only if the long-run price is at or above their minimum average cost, denoted by $m=\min _{y} c(y) / y$. In other words, they can survive only if the output supplied by profit-deviators cannot satisfy demand at a price lower than $m$. More precisely, given a demand function $D(p)$, profit-maximizers can exist only if

$$
D(p)>A \int y(p \mid \alpha) d G(\alpha), p \leq m,
$$

where $y(p \mid \alpha)$ is the supply function of type $\alpha$. For the marginal firm $\underline{\alpha}$ whose rents, but not necessarily profits, are zero, reinterpreted average cost equal price:

$$
p=\frac{C(y(p \mid \underline{\alpha}) \mid \underline{\alpha})}{y(p \mid \underline{\alpha})} .
$$

Only firms with enough altruism produce; that is, only firms with $\alpha \geq \underline{\alpha}$ are in the market. If demand is not met by supply at a price below minimum average cost $m$, the price rises to $m$, and profit-maximizers enter until excess demand is eliminated. Therefore, in the long run, when the supply of profit-maximizing firms is perfectly elastic, the market behaves as if there were only profit maximizers; long-run price gets driven down to minimum average cost, and long-run quantity is given by the market demand at this price. The long-run equilibrium is:

$$
\begin{aligned}
& p=m, \\
& Y=D(m) .
\end{aligned}
$$


Thus altruism confers a competitive advantage on profit-deviators. This conclusion differs from the common belief that when profit maximizers are driven to please their customers, they discipline the behavior of profit deviators in a competitive market. If profit maximizers price at minimum average costs, the argument goes, competitive markets force producers with output preferences to follow by eliminating "rents" which they might otherwise spend on output. ${ }^{29}$ Our analysis implies the opposite: competition allows profit deviators to drive out profit-maximizers even if the former have neither market power nor legal advantages.

\section{B. The Long-Run Neutrality of Antitrust for the Nonprofit Sector}

The NFP sector is defined by government regulations that distinguish it from the FP sector, in particular (a) tax exemptions and (b) the nondistribution constraint. ${ }^{30}$ Let $d$ indicate the regulatory choice of the firm, where $d=1$ when a firm chooses to be for-profit and $d=0$ when it decides to be nonprofit. The nonprofit firm is constrained to have economic profits below a certain regulated level $\pi \leq \pi_{R}$, while under for-profit status profits are unconstrained. Monetary cost functions differ across status: denoting by $c^{d}(y)$ the cost function in status $d$, we assume that $c^{0}(y)$ $\leq c^{1}(y)$ and $c_{y}{ }^{0}(y) \leq c_{y}{ }^{1}(y)$. Holding output fixed, both total and marginal costs are lower in the nonprofit sector. A firm in sector $d$ with preferences $v$ now has the reinterpreted marginal cost function $C_{y}{ }^{d}=c_{y}{ }^{d}-\left(v_{y} / v_{\pi}\right)$, with the supply function $y^{d}(p \mid v)$. Since nonprofit firms have to respect the distribution constraint, the respective profit functions for the two sectors are

$$
\pi^{0}=\min \left\{\pi_{R}, p y^{0}-c^{0}\left(y^{0}\right)\right.
$$

and

$$
\pi^{1}=p y^{1}-c^{1}\left(y^{1}\right)
$$


Antitrust in Nonprofit Sector

Presented with the option of nonprofit status, the firm chooses between the ability to retain positive profits and the ability to produce more output given nonprofit tax breaks.

Every profit-maximizing firm in the industry will choose for-profit status, because it does not value the extra output afforded by nonprofit tax breaks. Every profit-deviating firm, on the other hand, will choose nonprofit status, because the non-distribution constraint never binds it in equilibrium. To understand this result, consider first the case in which the marginal firm is profit maximizing. It earns zero profits at the equilibrium price $p$. Since all profit deviators are more altruistic than the profit-maximizing marginal firm, they will choose higher output and lower (negative) profits than the marginal firm. ${ }^{31}$ Now suppose that the marginal firm is profit deviating. It must be earning negative profits in order that its rents be driven to zero; all other profit deviators are at least as altruistic as the marginal firm and must also be earning negative profits. There will then be $N^{0}=A$ nonprofit firms, and $N^{1}$ for-profit firms covering residual demand at a price of minimum average cost

$$
N^{l} y^{l}(m \mid 0)=D(m)-A \int y^{0}(m \mid \alpha) d G(\alpha)
$$

The for-profit sector is thus composed of marginal firms (see Darius Lakdawalla and Tomas Philipson (1997) for a more comprehensive discussion of this result). As a result, industry behavior mimics that of an entirely for-profit industry, insofar as the long-run price is equal to minimum average cost when supply is perfectly elastic in the long run. We continue to have the neoclassical results that price reflect costs at the minimum efficient scale and quantity reflects demand at that price; $p=m$ and $Y=D(m)$. Put differently, one may understand the industry's response to an intervention, such as antitrust, without knowing anything about the share of output produced in the nonprofit sector. 
Antitrust in Nonprofit Sector

This has the counterintuitive implication that antitrust policy in the nonprofit sector may not affect consumer welfare. This is so when antitrust policy is fully enforced in the for-profit sector. In that case the for-profit sector will supply the residual amount of output not supplied in the non-profit sector at a price reflecting minimum average costs in the long run. Aggregate output will therefore be whatever demand is at that price regardless of what share of that output is produced by the nonprofit sector.

This result holds only for mixed industries, however, which in our analysis result from altruism being scarce relative to aggregate demand. If altruism is not scarce, there may only be nonprofits in the industry and then antitrust policy towards such firms may greatly affect consumer welfare.

\section{III: Antitrust Exemptions and Intellectual Property}

Patent, copyright, and trade secret law allows firms to obtain lawful monopolies of intellectual property and thus raises the question whether this regime is as appropriate for the NFP sector as it seems to be for the FP sector. The rationale for the law's permitting (indeed encouraging) these monopolies is that without protection from free riders, the creators of intellectual property would have insufficient incentives to invest in its creation, since they could have no confidence of being able to recover their fixed costs. The cost of making an additional copy of a piece of intellectual property is generally less than its average total cost and is sometimes quite close to zero even for intellectual property that may have cost a great deal to create. As patents are only valuable when the market power granted is exploited by the innovator, the issue then becomes whether an NFP firm will exploit market power to the degree necessary to generate sufficient innovation. Our analysis implies that patents may have larger effects on R\&D for altruistic firms 
even though they may price below costs when the product is marketed and therefore, mistakenly, look as if they are not exploiting market power.

More precisely, consider a firm that undertakes a level of $R \& D, z$, that results in an increasing and concave probability of discovery $p(z)$. Given the generalized optimal utility level $v(\alpha)$ for a producer with altruism $\alpha$, the producer's expected utility is

$$
E[v]=p(z) v(\alpha)-z .
$$

In the standard case of a profit maximizer $(v=\pi)$, this reduces to expected profits. The question is how the degree of altruism affects the degree to which $R \& D$ is encouraged through patents. If $z(v)$ denotes the R\&D undertaken in case of $v$ being the optimal level of utility when innovation is marketed, then $z(\alpha)=z(v(\alpha))-z(0)$ is the impact on $R \& D$ of allowing monopoly production. The chain rule implies that

$$
d z / d \alpha=(d z / d v)(d v / d \alpha)
$$

However, we know that the optimal R\&D is defined by the first-order condition

$$
p_{Z} v=1
$$

Therefore, provided that $p$ is concave so that there are diminishing returns to $R \& D$, expenditures on $\mathrm{R} \& \mathrm{D}$ will rise with the value of production: $d z / d v>0$. In addition, we know that altruistic firms are the low-cost firms in a market, so that the value of production will rise with the degree of altruism: $d v / d \alpha>0$. Consequently, patent protection has larger effects on expenditures on $R \& D$ for altruistic than for nonaltruistic firms even though the former may price below costs and therefore mistakenly appear not to be exploiting market power.

Since patents are valuable only if they confer market power in the sense of enabling the patentee to charge a price in excess of marginal cost, enabling patentee to recapture the fixed costs 
Antitrust in Nonprofit Sector

that it expended on the R\&D that enabled the patent to be obtained, the fact that NFP firms do seek patent protection shows that they are willing to exploit market power. However, market power used solely to recover fixed costs, rather than to generate rents, is benign, which is the justification for the antitrust exemption of the patent monopoly. But in this respect there is no difference between NFP and FP firms.

But suppose that the NFP patentees are altruistic in an industry sense, that is, they value industry output and not merely their own output. ${ }^{32}$ Then the NFP firms will not care quite as much about obtaining patents because they want to encourage the use of their innovations rather than simply wanting to increase their own revenues. But since, as we have emphasized, NFPs are not insensitive to costs, and lost revenues are the equivalent of incurred costs, they may still want to seek patent protection.

Lastly, patenting by a NFP firm can simply be viewed as a special case of crosssubsidization when the firm cares about a consumer group that does not buy the patented product and the firm uses the profits obtained from the patent to subsidize that group. In this case, the patent monopoly is used as a method of cross-subsidization that has the same negative welfare effects as discussed above.

\section{Conclusion}

Despite the conceptual differences between for-profit and nonprofit firms stressed in conventional economic analyses of the nonprofit sector, U.S. antitrust law generally does not distinguish between these two organizational forms. This paper defends that approach by demonstrating that the same incentives to restrain trade exist in the nonprofit sector as in the for-profit sector. Altruistic firms benefit from exploiting market power, just as non-altruistic ones do, even when the 
Antitrust in Nonprofit Sector

altruistic firms would price below marginal cost without the spur of competition. Therefore, promoting competition is socially valuable regardless of the particular objectives of producers, and the fact that antitrust law does not distinguish between the two sectors is efficient.

The paper has ignored several issues that may be fruitfully addressed by future research. First, the regulations defining the NFP sector bars such firms from raising capital through equity markets, but presumably few shareholders would be interested in firms pricing below cost which is the norm in the NFP sector in which donations partly cover production costs. As we have assumed, donors are essentially the shareholders in this respect. In a profit-maximizing world, shareholders all agree that the firm should maximize profits as it raises incomes of all shareholders. However, an important issue regarding the unanimity of the goal of the firm arises for altruistic firms because it will likely not be agreement among donors as to the right course of action of the firm. In addition, the market for corporate control is missing so that some donors cannot pay others to have their say in the behavior of the firm. Therefore, NFP firms will be more likely to be disciplined by output markets rather than input markets or corporate control in this respect, which in turn makes antitrust regulations particularly important.

Second, as our analysis captured only certain forms of utility distinct from that of owners of profit-maximizing firms, more general forms of utility functions should be considered in future work. However, the general misalignment between social and firm objectives that forms the basis of antitrust policy is likely to be present for many more general formulations.

Lastly, the paper did not address fully the impact of antitrust policy in oligopoly markets. The theory of the industrial organization of NFP industries is relatively poorly developed and as 
Antitrust in Nonprofit Sector

a result the impact of procompetitive policy poorly understood. Much more research in this area seems warranted. 
Antitrust in Nonprofit Sector

References

Areeda, Phillip E. and Hovenkamp, Herbert. Antitrust law: An analysis of antitrust principles and their application, rev. ed. Vol. IA. New York: Aspen Law \& Business, 1997.

Bamberger, Gustavo E. and Dennis W. Carlton. “Antitrust and Higher Education: MIT Financial Aid (1993),” in John E. Kwoka, Jr. and Lawrence J. White, eds., The antitrust revolution: Economics, competition and policy, 3d ed., New York: Oxford University Press, 1999, pp. 264-85.

Blackstone, Erwin A. and Joseph P. Fuhr. "An Antitrust Analysis of Non-Profit Hospital Mergers.” Review of Industrial Organization, 1993, 8(4), pp. 473-90.

Blumstein, James F. "The Application of Antitrust Doctrine to the Healthcare Industry: The Interweaving of Empirical and Normative Issues.” Indiana Law Review, 1998, 31(1), pp. 91117.

Capps, Cory S.; Dranove, David; Greenstein, Shane and Satterthwaite, Mark. "Antitrust Policy and Hospital Mergers: Recommendations for a New Approach.” Antitrust Bulletin, 2002, 47(4), pp. 677-714.

Conners, Jennifer R. “A Critical Misdiagnosis: How Courts Underestimate the Anticompetitive Implications of Hospital Mergers.” California Law Review, 2003, 91(2), pp. 543-77.

Dranove, David and Ludwick, Richard. "Competition and Pricing by Nonprofit Hospitals: A Reassessment of Lynk's Analysis.” Journal of Health Economics, 1999, 18(1), pp. 87-98.

Fleisher, Arthur A.; Goff, Brian L. and Tollison, Robert D. The National Collegiate Athletic Association: A study in cartel behavior. Chicago: University of Chicago Press, 1992. 
Antitrust in Nonprofit Sector

Gaynor, Martin and Vogt, William B. “Competition among Hospitals.” National Bureau of

Economic Research, Inc., NBER Working Papers: No. 9471, Jan. 2003.

Gaynor, Martin and Vogt, William B. “Antitrust and Competition in Health Care Markets,” in

Joseph P. Newhouse and Anthony J. Culyer, eds., Handbook of health economics. Vol. 1, part 2. New York: North-Holland, 2000, pp. 1405-87.

Gruber, Jonathan. “The Effect of Competitive Pressure on Charity: Hospital Responses to Price Shopping in California.” Journal of Health Economics, 1994, 13(2), pp. 183-212.

Hansmann, Henry. (1981), “The Rationale for Exempting Nonprofit Organizations from Corporate Income Taxation.” Yale Law Journal, 1981, 91(1), pp. 54-100.

Japsen, Bruce. “An Off Year For Consolidation.” Modern Healthcare, 12 January 1998, p. 40.

Jacquemin, Alexis and Slade, Margaret E. “Cartels, Collusion, and Horizontal Merger,” in Richard Schmalensee and Robert D. Willig, eds., Handbook of industrial organization. New York: North-Holland, 1989, pp. 415-73.

James, Estelle and Rose-Ackerman, Susan. The nonprofit enterprise in market economics. New York: Harwood Academic Publishers, 1986.

Keeler, Emmett B.; Melnick, Glenn and Zwanziger, Jack. “The Changing Effects of Competition on Non-Profit and For-Profit Hospital Pricing Behavior.” Journal of Health Economics, 1999, 18(1), pp. 69-86.

Kessler, Daniel P. and McClellan, Mark B. “Is Hospital Competition Socially Wasteful?” National Bureau of Economic Research, Inc., NBER Working Papers: No. 7266, July 1999.

Koch, James V. “A Troubled Cartel: The NCAA.” Law and Contemporary Problems, 1973, 38(1), pp. 135-50. 
Antitrust in Nonprofit Sector

Kopit, William G. and McCann, Robert W. "Toward a Definitive Antitrust Standard for Nonprofit Hospital Mergers.” Journal of Health Politics, Policy and Law, 1988, 13(4), pp. 63562.

Lakdawalla, Darius and Philipson, Tomas, “The NFP Sector and Industry Performance.” Journal of Public Economics (forthcoming)(citing 1997 draft).

Landes, William M. and Posner, Richard A. “Market Power in Antitrust Cases.” Harvard Law Review, 1981, 94(5), pp. 937-96.

Leibenluft, Robert F. “Antitrust Enforcement and Hospital Mergers: A Closer Look,” presented at the First Friday Forum of the Alliance for Health, Grand Rapids, Michigan, June 5, 1998.

Lynk, William J. "Nonprofit Hospital Mergers and The Exercise of Market Power.” Journal of Law \& Economics, 1995, 38(2), pp. 437-61.

Lynk, William J. and Neumann, Lynette R. "Price and Profit.” Journal of Health Economics, 1999, 18(1), pp. 99-116.

Malani, Anup; Philipson, Tomas and David, Guy. 'Theories of Firm Behavior in the Nonprofit Sector: A Synthesis and Empirical Evaluation,” in Edward L. Glaeser, ed., The governance of not-for-profit organizations. Chicago: University of Chicago Press, 2003, pp. $181-216$.

Meyer, David L. and Rule, Charles F. "Health Care Collaboration Does Not Require Substantive Antitrust Reform.” Wake Forest Law Review, 1994, 29(1), pp. 169-214.

Nelson, Melanie K. “The Anticompetitive Effects of Anti-Abortion Protest.” University of Chicago Legal Forum, 2000, pp. 327-68. 
Antitrust in Nonprofit Sector

33

Newhouse, Joseph P. "Toward a Theory of Nonprofit Institutions: An Economic Model of a Hospital.” American Economic Review, 1970, 60(1), pp. 64-74.

Norgard, Tara. "How Charitable is The Sherman Act?” Minnesota Law Review, 1998, 83(5), pp. 1515-53.

Ordover, Janusz A. and Saloner, Garth. "Predation, Monopolization, and Antitrust," in Richard Schmalensee and Robert Willig, eds., Handbook of industrial organization. New York: North-Holland, 1989, pp. 537-96.

Reiffer, Matthew. “Antitrust Implications in Nonprofit Hospital Mergers.” Journal of Legislation, 2001, 27(1), pp. 187-214.

Saville, John B. and Vincequerra, James. “Antitrust Issues of Non-Profit Hospital Mergers.” St. John’s Journal of Legal Commentary, 1998, 13(2), pp. 427-56.

Simpson, John and Shin, Richard. “Do Nonprofit Hospitals Exercise Market Power?” International Journal of the Economics of Business, 1998, 5(2), pp. 141-57.

Sloan, Frank A.; Picone, Gabriel A.; Taylor, Donald H. and Chou, Shin-Yi. "Hospital Ownership and Cost and Quality of Care: Is There a Dime’s Worth of Difference?” Journal of Health Economics, 2001, 20(1), pp. 1-21.

Stigler, George J. "The Dominant Firm and the Inverted Umbrella," in George J. Stigler, ed., The organization of industry. Chicago: University of Chicago Press, 1983, pp. 108-12. Reprint of the 1st ed., 1968.

Vaughn, Amanda J. “Introduction.” Vanderbilt Law Review, 1999, 52(2), pp. 557-98.

Viscusi, W. Kip; Vernon, John M. and Harrington, Joseph E., Jr. Economics of regulation and antitrust, 2d ed. Cambridge, MA: MIT press, 1995. 
Antitrust in Nonprofit Sector

Weisbrod, Burton A., ed. To profit or not to profit: The commercial transformation of the nonprofit sector. New York: Cambridge University Press, 1998.

Young, Gary J.; Desai, Kamal R. and Hellinger, Fred J. “Community Control and Pricing Patterns of Nonprofit Hospitals: An Antitrust Analysis.” Journal of Health Politics, Policy and Law, 2000, 25(6), pp. 1051-81.

\footnotetext{
${ }^{1}$ The U.S. antitrust laws are concerned with two broad categories of firm behavior. The first consists of efforts by which a firm collaborates with competing firms in an effort to reduce competition, ordinarily charged as a violation of section 1 of the Sherman Act or section 7 of the Clayton Act. The second consists of efforts by a firm, ordinarily one having monopoly power, to eliminate or reduce competition without collaborating with its competitors, violating either sections 1 or 2 of the Sherman Act or various sections of the Clayton Act.

${ }^{2}$ Health-care providers, particularly hospitals, dominate the NFP sector with about 50 percent of employment. Education and research make up the second largest component of NFP employment, at about 20 percent, followed by social services, such as child-care and job-training, at about 15 percent.

${ }^{3}$ See The American Hospital Association (www.aha.org) and Cory S. Capps et al. (2002).

${ }^{4}$ For a review of the literature see, e.g., Burton A. Weisbrod (1998) or Frank A. Sloan et al. (2001).

${ }^{5}$ See, e.g., Henry Hansmann (1981).

${ }^{6}$ See, e.g., Joseph P. Newhouse (1970).

${ }^{7}$ See William G. Kopit and Robert W. McCann (1988); United States v. Carilion Health System, 707 F. Supp. 840 (W.D. Va. 1989); FTC v. Freeman Hosp., 911 F. Supp. 1213 (W.D. Mo. 1995); William J. Lynk (1995); FTC v. Butterworth Health Corp., 946 F. Supp. 1285 (W.D. Mich. 1996); United States v. Long Island Jewish Med. Ctr., 983 F. Supp. 121 (E.D.N.Y. 1997); John B. Saville and James Vincequerra (1998); Matthew Reiffer (2001).

${ }^{8}$ See Erwin A. Blackstone and Joseph P. Fuhr (1992); David L. Meyer and Charles F. Rule (1994); United States v. Mercy Health Services, 902 F.Supp. 968 (N.D. Iowa 1995), vacated as moot, 107 F.3d 632 (8th Cir. 1997); Phillip E. Areeda and Herbert Hovenkamp (1997); James F. Blumstein (1998); Robert F. Leibenluft (1998); John Simpson
} 
and Richard Shin (1998); Emmett B. Keeler et al. (1999); Amanda J. Vaughn (1999); Melanie K. Nelson (2000); Gary J. Young et al. (2000); Jennifer R. Conners (2003); Martin Gaynor and William B. Vogt (2003).

${ }^{9}$ See, for example, National Collegiate Athletic Ass'n v. Board of Regents, 468 U.S. 85, 100 n. 22 (1984); Hospital Corp. of America v. FTC, 807 F.2d 1381, 1390-1391 (7th Cir. 1986).

${ }^{10}$ See, for example, American Column \& Lumber Co. v. United States, 257 U.S. 377 (1921); National Society of Professional Engineers v. United States, 435 U.S. 679 (1978); Northwest Wholesale Stationers, Inc. v. Pacific Stationery \& Printing Co., 472 U.S. 284 (1985).

${ }^{11}$ See, for example, National Collegiate Athletic Ass'n v. Board of Regents, note 9 above; United States v. Brown University, 5 F.3d 658 (3d Cir. 1993).

${ }^{12}$ See, for example, United States v. Rockford Memorial Corp., 898 F.2d 1278 (7th Cir. 1990).

${ }^{13}$ However, see the review by Gaynor and Vogt (2000) on antitrust for health care industries. An exception on which we build is Darius Lakdawalla and Philipson (1997).

${ }^{14}$ See, e.g., Lynk (1995); Bruce Japsen (1998); Simpson and Shin (1998); David Dranove and Richard Ludwick (1999); Keeler et al. (1999); Daniel P. Kessler and Mark B. McClellan (1999); and Lynk and Lynette R. Neumann (1999).

${ }^{15}$ The most general level of analysis of a utility maximizing firm would have him not only choose output but also inputs maximize a utility function $u(m, y, x)$ subject to feasibility constraints. Generalizing to include input choices in this way leads to many analogous results to the ones discussed when there is monopsony power, but makes exposition more cumbersome. As long as there is no input preferences, the conditional demand function for a profitmaximizer and utility-maximizing firm coincide. See Lakdawalla and Philipson (2000) for a discussion of the effects of input preferences on cost-functions.

${ }^{16}$ Note that the share of donations of revenue or cost is not a good indicator of whether there is output preference or not. For example, it often argued that in the U.S. hospitals industry, in which donations as a share of revenues or costs have fallen over time, profit-maximization is the relevant objective of the firm. However, this seems inconsistent with the firm choosing to be in the non-profit sector.

${ }^{17}$ For empirical support of this theory in the case of a mixed industry see Gaynor and Vogt (2003). 
${ }^{18}$ One may first think that whenever producer and consumer welfare coincide, $v(y)=s(y)$, then the private incentives of the firm coincide with social welfare maximization. However, in this case no optima exist as social and producer welfare is strictly increasing in output everywhere.

${ }^{19}$ An illustrative special case is where preferences are of the quasi-linear form, as would be the case under a firstorder Taylor approximation of any utility function

$$
v(y)=u(\pi, y)=\pi+\alpha y
$$

when the socially optimal markdown below costs is $p=c_{y}-\alpha$. The altruistic firm will price at

$$
\left[p-\left(c_{y}-\alpha\right)\right] / p=1 / e
$$

where $e=\left|-y_{p} p / p\right|$ is the demand-elasticity. Hence, the altruistic monopolist may be charging below cost but restraining trade at the same time.

${ }^{20}$ See Gustavo E. Bamberger and Dennis W. Carlton (1999). A complicating factor, however, is that if the best students are complements to faculty, the loss of those students may be experienced as a cost to the faculty, thus requiring the colleges to raise salaries in order to restore the wage equilibrium. However, this assumes that the bidding wars have a significant effect on the assignment of students to colleges, and they may not. The students may end up at the same schools, only with higher rents.

${ }^{21}$ See Arthur A. Fleisher et al. (1992); James V. Koch (1973).

${ }^{22}$ A similar argument holds for a constant elasticity demand curve with $p(y)=y^{-1 / \varepsilon}$, with $\varepsilon>1$. In this case, the deadweight loss is $L(\alpha)=K(\varepsilon)(c-\alpha)^{1-\varepsilon}$ where $K(\varepsilon)$ is a positive constant that depends on the elasticity of demand. Thus, this again implies that the deadweight loss rises with altruism.

${ }^{23}$ Such altruistic discrimination does not violate the non-distribution constraint that defines the NFP sector because the constraint applies to the organization as a whole rather than to each separate line of business or consumers.

${ }^{24}$ For empirical support of this theory, see Jonathan Gruber (1994).

${ }^{25}$ This relation has implications for the regulatory treatment of "unrelated business income.” If the alleged "unrelated business" is a complement to the NFP's main, altruistic mission, then it isn't really unrelated—it promotes the fulfillment of the mission. But this is a topic outside the scope of the present paper. 
${ }^{26}$ See William M. Landes and Richard A. Posner (1981).

${ }^{27}$ For example, we could have $v(y, \pi(y))=\alpha y+(1-\alpha) \pi(y)$.

${ }^{28}$ Given the cost-function $c(y)$, its reinterpreted counterpart satisfies:

$C(y \mid \alpha)=\int_{0}^{y}\left[c_{y}(\theta)-\frac{v_{y}(\theta, \pi \mid \alpha)}{v_{\pi}(\theta, \pi \mid \alpha)}\right] d \theta$.

This implies, as assumed throughout, that $C_{y}(y \mid \alpha)$ falls in $\alpha$.

${ }^{29}$ See, for example, Estelle James and Susan Rose-Ackerman (1986).

${ }^{30}$ The nondistribution constraint has certain market consequences that we do not discuss in this paper. In particular, the NFP sector cannot raise capital in the equity markets because it cannot offer a profit incentive to investors. As a result, there is no market for corporate control of NFP institutions, and so there can be no hostile takeovers of such institutions, as there can be in the FP sector, by means of tender offers, although of course friendly takeovers remain possible. Despite the differences between the two sectors in terms of corporate control, both forms of organizations co-exist under competitive conditions in many industries, which may suggest that output competition is a more important mechanism for disciplining a firm than competition in the market for corporate control.

${ }^{31}$ To see that profits fall in altruism, observe that a firm with utility $v(y, \pi(y))$ will respect the first order condition $v_{y} / v_{\pi}=c_{y}-p$. Since $v_{y} / v_{\pi}$ is a measure of altruism, the more altruistic firms will choose a higher cost-price differential. In other words, more altruism leads to higher output and lower profits.

${ }^{32}$ A related issue is whether government-funded R\&D should be patentable. It is related because government funded R\&D operates to replace voluntary donors with involuntary taxpayers who are unlikely to have a preference for the output of any particular firm. 